\title{
Performance of Chicks Submitted to Fasting Post- Hatching and with Maltodextrine Supplementing to Diet as Hydrating and Energetic Additive
}

\section{-Author(s)}

\section{Machado $\mathrm{CA}^{\prime}$ \\ Fernandes EA" \\ Carvalho LSS'II \\ Litz FH" \\ Gotardo LRM ${ }^{\text {IN }}$ \\ Braga PFS'V}

MscVeterinarian, Veterinary Sciences UFU (cm.camilavet@gmail.com)

" Professor at FAMEV/PPGCV/UFU (evandrof@umuarama.ufu.br)

III Veterinary Science PhD student at UFU (leticiasouzavet@hotmail.com, fernandalitz@veterinaria.med.br)

iv Veterinary Science master's student at UFU (luciana.ruggeri@hotmail.com, paulinhafsb@hotmail.com)

Project founded by CARGIL AGRICOLA

\section{ABSTRACT}

This study aimed to evaluate the effect of maltodextrin on performance of chicks passed through four fasting periods. A completely randomized design was performed, consisting of three treatments (1 - control, 2 $4 \%$ saccharose; $3-4 \%$ maltodextrin 20$)$ and four fasting periods after hatching $(0,12,24$ and 36 hours) with four replications, totaling 1920 birds of both sexes. The studied variables were: water intake in the first 12 hours, average food intake, average body weight and real feed conversion. Data was submitted to analysis of variance and means were compared with each other by Dunnett test at $5 \%$ significance. The use of additives and imposing of different fasting periods did not influence the performance at 42 days old. Therefore, fasted chicks consumed significantly more water. At 7 days old, chicks fasted showed higher body weight and higher feed intake, however, the viability did not suffer any influence, the weight remained higher after 21 days with the fast imposition and there was no influence on other variables. There was no effect of fasting on broiler chiken's performance at 42 days old. The inclusion of sucrose and maltodextrin to drinking water stimulated the chick's water intake and provided higher viability after seven days old.

\section{INTRODUCTION}

In commercial conditions, newborn chicks are submitted to food or water restriction for 36-48 hours, which can negatively influence the development of the gastrointestinal tract, immune system, and consequently, the broiler chicken's performance (Dibner \& Knight, 1999). This fasting time is partly due to the multistage system where incubators hatch different weight eggs, with different storage periods and produced by breeders with different ages, simultaneously. Practice that provides less uniformity of the chicks in the hatcher, subjecting the chicks to excessive periods of fasting (Tona, 2003).

Until the chick's adaption to food intake occurs, the foodborne carbohydrates availability is minimal after hatching, requiring glucose production via gluconeogenesis from protein and lipid source (Vieira \& Moran, 1998). Thus, the dependence of fat for energy production coupled to insufficient glucose availability can lead the newly hatched chicks to ketosis (Best, 1966) which reduces the metabolic availability of water necessary for the chick's rehydration (Hammond, 1944).

In an attempt to mitigate the negative effects of post-hatching fasting, several researches have studied the effectiveness of supplements offered to the chicks during transportation and reception, to minimize the negative impacts on broiler's performance. This is a way to provide nutrients to the chicks before they have access to food and water.

The chick's carbohydrate supplementation after hatching is an alternative in reducing gluconeogenesis, by preventing that the yolk sac proteins, essential to immunity, are consumed for power supply. Accordingly, 
maltodextrin supplementation can be an alternative to preserve the development, and consequently, the performance of newly hatched chicks.

Maltodextrin is produced by the partial hydrolysis of starch, formed by maltose and dextrin units; therefore, it is a simple sugar source capable of providing energy and restoring blood glucose levels in animals. According to Augusto et al. (2011) maltodextrin stimulates the specific enzymes secretion, induced by the carbohydrate presence in the gut of swines contributing to performance maintenance.

Several surveys have shown maltodextrin's efficiency to replace the lactose in piglet diets (Oliver et al., 2002; Hauptili et al., 2007; Silva et al., 2008) in addition to its prebiotic effect on piglets (Bomba et al. 2002; Liong \& Shah, 2005) and dogs (Flickinger et al., 2000), however it's effects on the broiler chicken's development have not yet been described.

Thus, the aim of this research was to evaluate the performance of broiler chicken subjected to post-hatching fasting and greeted with maltodextrin as a moisturizer energy additive.

\section{MATERIALS AND METHODS}

The eggs from the broiler breeder Cobb Avian $48^{\circledR}$ of 50 weeks of age were ranked according to weight. The eggs input in hatching was designed to obtain chicks hatched 36, 24,12 and zero hours before the date and time set for the animal's housing in the experimental farm.

The hatched chicks after being sexed, weighed and vaccinated against Gumboro and Marek's disease were fasted in the hatchery in a room with average relative humidity of $60 \%$ and temperature between 24 to $28^{\circ} \mathrm{C}$, kept in cardboard box, where the average temperature was $6^{\circ} \mathrm{C}$ to $8^{\circ} \mathrm{C}$ above the room temperature, hence within the optimum temperature $\left(30\right.$ to $\left.36^{\circ} \mathrm{C}\right)$.

The barn where the experiment was conducted presents masonry construction, metal frame and fibro-cement roof with sidewalls in wire mesh. Inside, the ceiling was lined with poultry plastic curtain and side protected with dark curtains of the same material.

The bird's were housed in pens $(1,90 \mathrm{~m}$ $x 1,50 \mathrm{~m})$, up to 40 birds each, which were equipped with a drinker pressure cup type for the initial stage and a pendulum drinker for the remainder-rearing period, plus a tubular feeder with a capacity of 25 kilograms of feed. On housing, considered as the first experiment day, the chick's heating was carried out by gas hoods distributed in the ratio of one for every four pens. In growing and finishing stages, the house environment was controlled with fans and sprinklers help.

Twenty male chicks and twenty female chicks were distributed per pen, totalling 1920 broiler chicken of both sexes. They remained in the pens until 42 days of age. They were slaughtered at 43 days of age. Thus, the distribution of the experiment was conducted in a completely randomized design with factorial arrangement $3 \times 4$, with three feed formulations (1$4 \%$ sucrose, $2-4 \%$ maltodextrin 20) and four fasting periods $(0,12,24$ and 36 hours), being three treatments and four replications.

The diets ad libitum, divided into four stages according to the age, were formulated and produced with the levels recommended by Rostagno et al. (2005) (Table 1).

Table 1 - Percentage and calculated composition of the experimental diets

\begin{tabular}{lcccc}
\hline Ingredients & $\begin{array}{c}\text { Pre-starter } \\
(1-7 \text { days })\end{array}$ & $\begin{array}{c}\text { Starter } \\
(8-21 \text { days })\end{array}$ & $\begin{array}{c}\text { Growing } \\
(22-33 \text { days })\end{array}$ & $\begin{array}{c}\text { Slaughtering } \\
\text { (34-42 days) }\end{array}$ \\
\hline Corn & 55,68 & 54,18 & 58,20 & 64,41 \\
Soybean meal & 36,87 & 36,36 & 32,53 & 26,92 \\
Oil & 3,09 & 5,46 & 5,54 & 5,15 \\
Bicalcium Phosphate & 2,08 & 1,83 & 1,85 & 1,72 \\
Limestone & 0,91 & 0,95 & 0,84 & 0,83 \\
Salt & 0,39 & 0,40 & 0,35 & 0,36 \\
L-lisine & 0,28 & 0,13 & 0,06 & 0,12 \\
DL-Methionine & 0,29 & 0,29 & 0,23 & 0,20 \\
Premixvit.+mineral & 0,401 & 0,401 & 0,402 & 0,303 \\
Total & 100 & 100 & 100 & 100 \\
\hline Composition & & & & \\
\hline ME (kcal/kg) & 2960 & 3050 & 3150 & 3200 \\
Crude Protein (\%) & 22,90 & 22,83 & 19,73 & 18,31 \\
Lisine (\%) & 1,46 & 1,30 & 1,19 & 1,14 \\
Methionine (\%) & 0,69 & 0,58 & 0,55 & 0,53 \\
Met+Cist.(\%) & 1,05 & 0,93 & 0,87 & 0,75 \\
Calcium(\%) & 0,95 & 0,90 & 0,84 & 0,80 \\
Available Phosph. (\%) & 1,89 & 0,45 & 0,42 & 0,39 \\
Sodium (\%) & 0,22 & 0,22 & 0,21 & 0,2 \\
\hline
\end{tabular}

'MC-Mix Starter chicken 4kg - Composition per kg of feed - Vit-A 11.000IU; D3 2.000IU; E 16mg; FolicAcid 400mcg; Panthotenatecalcium 10mg; Biotin 60mcg; Niacin 35mg; Piridoxin 2mg; Riboflavin 4,5mg; Tiamin 1,2mg; B12 16mcg; Potassium 1,5mg; Se 250mcg; Choline 249mg; Methionine 1,6g; Cu 9mg; Zn 60mg; I $1 \mathrm{mg}$; Iron 30mg; Mn 60mg; Promoter 384mg; Coccidiostatic 375mg; Antioxidant 120mg.

${ }^{2}$ MC-Mix Growing chicken 4kg - Composition per kg of feed - Vit-A 9000IU; D3 1600IU; E 14mg; Folic Acid 300mcg; Panthotenatecalcium 9mg; Biotin 50mcg; Niacin 30mg; Piridoxin 1,8mg; Riboflavin 4mg; Tiamin 1mg; B12 12mcg; K3 1,5mg; Se 250mcg; Choline 219mg; Methionine 154g; Cu 9mg; Zn 60mg; I 1mg; Iron 30mg; Mn 60mg; Promoter 385mg; Coccidiostastic 550mg; Antioxidant 120mg

${ }^{3}$ MC-Mix Slaughtering chicken 3kg - Composition per Kg of feed - Vit-A 2.700IU; D3 450IU; E 4,5mg; Panthotenatocalcium 3,6mg; Biotin 13,5mcg; Niacin 4,5mg; Piridoxin 360mcg; Riboflavin 900mcg; Tiamin 270mcg; B12 2,7mcg; K3 450mcg; Se 180mcg; Choline 130mg; Methionine 906mg; Cu 9mg; Zn 60mg; I $1 \mathrm{mg}$; Iron 30mg; Mn 60mg; Antioxidant 120mg. 
Machado CA, Fernandes EA,

Carvalho LSS, Litz FH,

Gotardo LRM, Braga PFS
Performance of Chicks Submitted to Fasting PostHatching and with Maltodextrine Supplementing to Diet as Hydrating and Energetic Additive
The feed and the broiler chicken were weighed at 7 , 21 and 42 days of age (the last day of the diet delivery) and the effects of fasting times on the performance were evaluated by monitoring the following variables: water intake in the first 12 hours, average food intake, average body weight and real feed conversion (RFC).

All performance characteristics were stated in cumulative periods. The data was submitted to ANOVA and means were compared with each other by Dunnett test at 5\% significance at SISVAR program.

\section{RESULTS AND DISCUSSION}

Broiler chickens fasted consumed significantly more water than the broilers housed and fed right after hatching (Table 2), and the water intake increased linearly according to the equation $y=5.02695+$ $0,27974 x$, as intensified fasting, where birds fasted 36 hours, ingested approximately 3.2 times more water than those housed after hatching.

Table 2 - Water consumption ( $\mathrm{mL} /$ bird) within the first 12 hours of chicks housing subjected to four fasting periods after hatching and two additives via water.

\begin{tabular}{|c|c|c|}
\hline Fasting period (hours) & & Water intake $(\mathrm{mL})$ \\
\hline 0 & & $4,72^{b}$ \\
\hline 12 & & $9,47^{a}$ \\
\hline 24 & & $11,21^{a}$ \\
\hline 36 & & $15,09^{a}$ \\
\hline Regression & & Linear $^{1}$ \\
\hline \multirow{3}{*}{ Additives } & Control & $7,77^{b}$ \\
\hline & Sucrose & $10,84^{a}$ \\
\hline & Maltodextrine & $11,75^{a}$ \\
\hline \multirow[t]{2}{*}{ CV (\%) } & & \\
\hline & Fasting & $<0,0001$ \\
\hline \multirow[t]{2}{*}{$p$ value } & Additive & $<0,0001$ \\
\hline & Fasting/Additive & 0,3641 \\
\hline
\end{tabular}

Means followed by different small letters in the same column differ by Dunnet test $(p<0.05)$.

${ }^{1} R^{2}=0.6945 y=5.02695+0,27974 x$

According to Leeson \& Summers (2000), there was direct relation between water and feed intake, once the feed restriction had influence on water intake which increased when the broiler chickens had access to food. At the end of the water restriction, animals had the maximum amount of water allowed by their physical limit (Brooks, 1994).

The water intake was higher with the addition of maltodextrine and sucrose, which possibly occurred due to the presence of tactile and taste buds on the tongue arranged on its base (Boleli et al., 2002), which may have aided the chicks in the food selection. Currently, the broiler has a high growth rate of about 55 grams per day, and therefore presents very high met- abolic activity. This is the reason why water intake performs a vital and constant function, in comparison with other species (Bruno \& Macari, 2002).

The body weight at seven days of age (Table 3) was influenced in cubic form by fasting time, being higher in chicks fasted. A similar result to Cançado \& Baião (2002), who observed that birds passed through fasting for 24 to 48 hours, proved to be heavier than those housed and fed right after hatching. According to Soares et al. (2007), in animals subjected to dietary restriction there was a decrease in nutrients demand for maintenance, resulting in increased nutrient use efficiency for growth (Doyle \& Leeson, 1997). Likewise, Castel et al. (1994) and Baião \& Borges (1995) reported that intervals between hatch and housing up to 48 hours did not influence or favored the weight gain.

The feed intake at seven days of age showed a quadratic effect (Table 3) and was higher in the chicks subjected to fasting for 24 hours, the other treatments had a significantly similar intake to the control group.

The feed conversion was affected linearly by fasting time, being better in broiler chicken fasted for 36 hours. Pedroso et al. (2005) also observed better feed conversion in poultry fasted for 48 hours. For the authors, newly hatched and immediately housed chicks did not show good feed conversion by having an endogenous source of nutrition. Thus, the interval between hatching and housing may provide better results, since the partial absorption of the yolk sac can contribute to a better utilization of the ingested diet. In this study, the highest body weight of fasted birds combined with real feed conversion (36 hours of fasting treatment) indicating a compensatory weight gain of these animals.

The viability was not affected by fasting imposition, results that corroborated with Teixeira's (2009) findings, who did not observe any effect of the treatments on bird mortality from one to seven days of age for fasting up to 40 hours.

The sucrose and maltodextrine inclusion in the chick's water intake had no influence on the variables for body weight, feed intake and real feed conversion. However, viability was higher in the broiler chickens fed with water with these additives, which differ from the results from Pedroso et al. (2005) who found no effect of commercial hydrating in reducing the bird's mortality subjected to post-hatching fasting.

In broiler chicken at 21 days old, body weight remained higher in birds subjected to fasting (Table 4), however no effect of fasting imposition was observed for feed intake and viability. Still, birds that suffered 24 and 36 hours of fasting showed better feed conversion. 
Table 3 - Body weigth (BW), feed intake (FI), real feed conversion (RFC) and viability (V) at seven day old chicks subjected to four periods of post-hatching fasting and greeted with additives via the drinking water.

\begin{tabular}{|c|c|c|c|c|c|}
\hline & & $\mathrm{BW}(\mathrm{kg})$ & $\mathrm{FI}(\mathrm{kg})$ & RFC & $\mathrm{V}(\%)$ \\
\hline \multirow{4}{*}{ Fasting period (hours) } & 0 & $0,170^{\mathrm{b}}$ & $0,184^{b}$ & $1,514^{\mathrm{a}}$ & $98,98^{a}$ \\
\hline & 12 & $0,183^{a}$ & $0,199^{b}$ & $1,471^{\mathrm{a}}$ & $99,79^{a}$ \\
\hline & 24 & $0,183^{a}$ & $0,210^{a}$ & $1,524^{\mathrm{a}}$ & $99,17^{\mathrm{a}}$ \\
\hline & 36 & $0,190^{\mathrm{a}}$ & $0,197^{\mathrm{b}}$ & $1,346^{b}$ & $99,15^{a}$ \\
\hline \multirow[t]{2}{*}{ Regression } & & Cubic $^{1}$ & Quadratic $^{2}$ & Linear $^{3}$ & ns \\
\hline & Control & $0,180^{\mathrm{a}}$ & $0,198^{a}$ & $1,472^{\mathrm{a}}$ & $98,44^{b}$ \\
\hline \multirow[t]{2}{*}{ Additive } & Sucrose & $0,181^{\mathrm{a}}$ & $0,195^{\mathrm{a}}$ & $1,449^{a}$ & $99,53^{a}$ \\
\hline & Maltodextrine & $0,183^{\mathrm{a}}$ & $0,200^{\mathrm{a}}$ & $1,471^{\mathrm{a}}$ & $99,84^{\mathrm{a}}$ \\
\hline VC (\%) & & 4,76 & 9,27 & 10,20 & 1,39 \\
\hline \multirow{3}{*}{$p$ value } & Fasting & $<0,0001$ & 0,0062 & 0,0167 & 0,3618 \\
\hline & Additive & 0,2369 & 0,6984 & 0,8825 & 0,0039 \\
\hline & Fasting/Additive & 0,2043 & 0,7568 & 0,8916 & 0,2370 \\
\hline
\end{tabular}

Means followed by different small letters in the same column and capital letters on the same line, differ from control by Dunnett's test $(p<0,05)$.

${ }^{1} R^{2}=0,7184, y=0,17007+0,0021 x 1-0,00010685 x^{2}+0,00000176 x^{3}$

${ }^{2} R^{2}=0,1995, y=0,18402+0,00207 x-0,00004702 x^{2}$

${ }^{3} R^{2}=0,0910, y=1,52728-0,00360 x$

Regarding the additives inclusion in drinking water, feed intake and viability no difference was found from the control treatment, but body weight and feed conversion were worse in birds greeted with sucrose as an additive (Table 4). According to Silva et al. (2008) the maltodextrine had lower osmolarity, which provided greater absorption of water and nutrients when compared to sucrose. Different results were reported by Silva et al. (2011) who observed higher body weight at 21 day old chicks that received supplements for 48 hours after hatching. Such differences were not observed by Pedroso et al. (2005) when water with electrolyte's presence or absence was provided to the chickens, this means that the electrolytes had no influence on the performance's variables in 21 day old broiler chicken.
Despite the differences observed in both fasting imposition, as in providing additives, at seven, twenty and 42 days of age (Table 5) there was no effect of fasting time as well as the addition of additives via drinking water on the evaluated performance variables.

These data corroborate with Pedroso's et al. (2005) findings, who did not observe influence of pre and post-hydrant on bird performance. Shafey et al. (2011) adding glucose to chick's water drink after hatching, also found no effect on the broiler's performance. Similar results were obtained by Baião et al. (1998) and Tanaka \& Xin (1997), who used respectively electrolytic and commercial hydrating solution and did not observe any benefits on the performance.

This study demonstrated that the post-hatching fasting imposition to broiler chicks did not affect the

Table 4 - Body weight (BW), feed intake (FI), real feed conversion (RFC) and viability (V) at 21 day old chicks subjected to four periods of post-hatching fasting and greeted with additives via drinking water.

\begin{tabular}{|c|c|c|c|c|c|}
\hline & & BW (kg) & $\mathrm{Fl}(\mathrm{kg})$ & RFC & $\mathrm{V}(\%)$ \\
\hline \multirow{4}{*}{ Fasting period (hours) } & 0 & $0,879^{b}$ & $1,328^{a}$ & $1,567^{a}$ & $98,71^{a}$ \\
\hline & 12 & $0,931^{a}$ & $1,325^{a}$ & $1,496^{a}$ & $99,37^{\mathrm{a}}$ \\
\hline & 24 & $0,939^{a}$ & $1,332^{\mathrm{a}}$ & $1,463^{b}$ & $98,75^{a}$ \\
\hline & 36 & $0,957^{a}$ & $1,336^{a}$ & $1,438^{b}$ & $98,10^{a}$ \\
\hline \multirow[t]{2}{*}{ Regression } & & Linear $^{1}$ & Ns & Ns & ns \\
\hline & Control & $0,934^{a}$ & $1,333^{\mathrm{a}}$ & $1,445^{b}$ & $97,76^{a}$ \\
\hline \multirow[t]{2}{*}{ Additive } & Sucrose & $0,899^{b}$ & $1,329^{a}$ & $1,550^{\mathrm{a}}$ & $99,22^{\mathrm{a}}$ \\
\hline & Maltodextrine & $0,947^{a}$ & $1,328^{\mathrm{a}}$ & $1,479^{b}$ & $99,22^{\mathrm{a}}$ \\
\hline VC (\%) & & 5,34 & 1,70 & 6,82 & 2,01 \\
\hline \multirow{3}{*}{$P$ value } & Fasting & $<0,0001$ & 0,6077 & 0,0017 & 0,4513 \\
\hline & Additive & 0,0025 & $0,78,31$ & 0,0022 & 0,0480 \\
\hline & Fasting/Additive & 0,6529 & 0,0903 & 0,2182 & 0,6276 \\
\hline
\end{tabular}

Means followed by different small letters in the same column and capital letters on the same line, differ from control by Dunnett's test $(p<0,05)$.

${ }^{1} R^{2}=0,0689 y=0,89263+0,00138 x$ 
Table 5 - Body weight (BW), feed intake (FI), real feed conversion (RFC) and viability (V) at 42 day old chicks subjected to four periods of post-hatching fasting and greeted with additives via drinking water.

\begin{tabular}{|c|c|c|c|c|c|}
\hline & & BW $(\mathrm{kg})$ & $\mathrm{FI}(\mathrm{kg})$ & RFC & $\mathrm{V}(\%)$ \\
\hline \multirow{4}{*}{ Fasting period (hours) } & 0 & $2,438^{a}$ & $3,998^{a}$ & $1,692^{\mathrm{a}}$ & $96,01^{a}$ \\
\hline & 12 & $2,419^{a}$ & $3,746^{a}$ & $1,596^{a}$ & $97,29^{a}$ \\
\hline & 24 & $2,447^{a}$ & $4,067^{a}$ & $1,708^{a}$ & $97,29^{\mathrm{a}}$ \\
\hline & 36 & $2,481^{a}$ & $4,208^{a}$ & $1,769^{a}$ & $95,37^{a}$ \\
\hline \multicolumn{2}{|l|}{ Regression } & $\mathrm{ns}$ & Ns & Ns & $\mathrm{Ns}$ \\
\hline \multirow{3}{*}{ Additive } & Control & $2,473^{a}$ & $4,064^{a}$ & $1,696^{a}$ & $95,58^{a}$ \\
\hline & Sucrose & $2,427^{a}$ & $3,969^{a}$ & $1,689^{a}$ & $96,41^{\mathrm{a}}$ \\
\hline & Maltodextrine & $2,438^{a}$ & $3,981^{\mathrm{a}}$ & $1,689^{a}$ & $97,49^{\mathrm{a}}$ \\
\hline \multicolumn{2}{|l|}{ VC (\%) } & 3,87 & 13,79 & 13,33 & 3,44 \\
\hline \multirow{3}{*}{$p$ value } & Fasting & 0,4801 & 0,2735 & 0,3737 & 0,4144 \\
\hline & Additive & 0,3718 & 0,8732 & 0,9940 & 0,2766 \\
\hline & Fasting/Additive & 0,7747 & 0,8572 & 0,8845 & 0,8085 \\
\hline
\end{tabular}

Means followed by different small letters in the same column and capital letters on the same line, differ from control by Dunnett's test ( $p<0.05)$.

chick's performance at the end of market age, showing sometimes the benefits of it's implementation on the performance variables at 07 and 21 days of age.

Both sucrose and maltodextrine stimulated the chick's body water intake right after housing, this fact is important, because water participates in almost all metabolic processes and is directly linked to feed intake and digestion. Despite that fact, the hydrants did not influence significantly the 42 day old broiler's performance, the viability at seven days old was significantly better in these treatments.

\section{CONCLUSION}

The inclusion of sucrose and maltodextrine in drinking water stimulated the chick's water intake and provided higher viability after seven days of age. Fasting for 36 hours after hatching did not damage the bird's performance at market age.

\section{REFERENCES}

Augusto RMN, Berto DALO, Terzo V, Mello G, Hauptli L, Lucchesi L. Maltodextrina em rações de leitões desmamados com diferentes pesos:desempenho e morfometria intestinal. Acta Scientiarum Animal Sciences 2011;33(1):41-46.

Baião NC, Borges FMO. Efeitos de hidratantes para pintos de corte no dia do alojamento sobre o desempenho de frangos. Arquivo Brasileiro de Medicina Veterinária e Zootecnia 1995;47(6):831-837.

Baião NC, Cançado SV, Lúcio CG. Efeito do período de incubação e do intervalo entre o nascimento e o alojamento de pintos sobre 0 desempenho do frango. Arquivo Brasileiro de Medicina Veterinária e Zootecnia 1998,50:329-35.

Best EE. The changes of some blood constituents during the initial posthatching period in chickens. II. Blood total ketone bodies and the reduced glutathione/ketone body relationship. British Poultry Science 1996;7:23-28.
Boleli IC, Maiorka A, Macari M. Estrutura funcional do trato digestório. In: Macari M, Furlan RL, Gonzáles E. Fisiologia aviária aplicada a frangos de corte. Jaboticabal: Funep/Unesp; 2002. p. 75-95.

Bomba A, Nemcová R, Gancarcíková S, Herich R, Guba P, Mudronová $D$. Improvement of the probiotic effect of micro-organism by their combination with maltodextrins, fructo-oligosaccharides and polyunsaturated fatty acids. British Poultry Science 2002;88:95-99 Supplement 1.

Brooks PH. Water - Forgotten nutrient and novel delivery system. Proceedings of the $10^{\circ}$ Alltech's annual symposium; 1994; Nottingham. England: Nottingham University Press;1994. p. 211-34.

Bruno LDG, Macari M. Ingestão de água:mecanismos regulatórios. In: Macari M, Furlan RL, Gonzales E. Fisiologia aviária aplicada a frangos de corte. Jaboticabal: Funep/Unesp; 2002. p. 201-208.

Cançado SV, Baião NC. Efeito do período de jejum entre o nascimento e o alojamento e da adição de óleo à ração sobre o desempenho de pintos de corte e digestibilidade da ração. Arquivo Brasileiro de Medicina Veterinária e Zootecnia 2002;54(6):630-635.

Casteel ET, Wilson JL, Buhr RJ. The influence of extend post hatch holding time and placement density onbroiler performance. Poultry Science 1994;73(11):1679-1684.

Dibner JJ, Knight CD. Early feeding and gut health in hatchlings. Positive Action Publications 1999;14(1):17- 21.

Doyle F, Leeson S. Compensatory growth farms animals. II. Methods of implementation and animal performance. Guelph, Ontario: Department of Animal and Poultry Science, University Guelph; 1997. p.85-103.

Flickinger EA, Wolf BW, Garleb KA, Chow J, Leyer GJ, Johns PW, Fahey GCJR. Glucose-based oligosaccharides exhibit different in vitro fermentation patterns and affect in vivo apparent nutrient digestibility and microbial populations in dogs. Journal of Nutrition 2000;130(5):1267-1273.

Hammond JC. Lack of water a cause of loose, slimy gizzard linings accompanying early mortality in poults. Poultry Science 1944;2(6):477480.

Hauptili L, Lovatto PA, Hauschild L. Comparação da adição de extratos vegetais e antimicrobianos sintéticos para leitões na creche através de meta-análise. Ciência Rural 2007;37(4):1084-1090.

Leeson S, Summers JD. Feeding system for poultry. In: Theodoroug MK, France J. editors. Feeding systems and feed evaluation models. Wallingford: CAB International; 2000. 
Machado CA, Fernandes EA,

Carvalho LSS, Litz FH,

Gotardo LRM, Braga PFS
Performance of Chicks Submitted to Fasting PostHatching and with Maltodextrine Supplementing to Diet as Hydrating and Energetic Additive
Liong MT, Shan NP. Optimization of cholesterol removal, growth and fermentation patterns of Lactobacillus acidophilus ATCC 4962 in presence of mannitol, fructo-oligosaccharide and inulin:a response surface methodology approach. Journal of Applied Microbiology 2005;98(5):1115-1126.

Oliver WT, Mathews SA, Phillips O, Jones EE, Odle J, Harrell RJ. Efficacy of partially hydrolyzed corn syrup solids as a replacement for lactose in manufactured liquid diets for neonatal pigs. Journal of Animal Science 2002;80(1):143-153.

Pedroso AA, Stringhini JH, Leandro NSM, Café MB, Barbosa CE, Lima FG. Suplementos utilizados como hidratantes nas fases pré-alojamento e pós-alojamento para pintos recém eclodidos. Pesquisa Agropecuária Brasileira 2005, 40(7):627-632.

Rostagno HS, Albino LFT, Donzele JL, Gomes PC, Oliveira RF, Lopes DC, et al. Tabelas brasileiras para aves e suínos:composição de alimentos e exigências nutricionais. Viçosa: UFV; 2005. 186p.

Shafey TM, Aljumaah RS, Almufarrej SI, Al-Abdullatif A.A; Abouheif M.A. Effects of glucose supplementation of drinking water on the performance of fasting newly hatched chicks. Journal of Animal and Veterinary Advances 2011;10:2202-2207.

Silva AMR, Berto DA, Lima GJMM, Wechsler FS, Padilha PM, Castro VS. Valor nutricional e viabilidade econômica de rações suplementadas com maltodextrina e acidificante para leitões desmamados. Revista Brasileira de Zootecnia 2008;37(2):286-295.
Silva CC, Gomes GA, Araújo LF, Barbosa LCGS, Araújo CSS, Petroli NB. Avaliação do tempo de jejum para alojamento pós-eclosão para frangos de corte. Anais do $22^{\circ}$ Latin American Poultry Congress; 2011 [cited 2012 Dec 02]. Available from: <http://pt.engormix.com/MA-avicultura/ industria-carne/artigos/avaliacao-tempo-alojamento-fornecimentot527/471-p0.htm>

Soares LF, Ribeiro AML, Penz Júnior AM, Ghiotti A. Influência da restrição de água e ração durante a fase pré-inicial no desempenho de frangos de corte até 42 dias de idade. Revista Brasileira de Zootecnia 2007;36(5)1579-1589.

Tanaka A, XIN H. Energetic, mortality, and body mass change of breeder chicks subjected to different post-hatch feed dosage. Transactions of the American Society of Agricultural Engineers 1997;40:1457-1461.

Teixeira ENM, Silva JHV Costa FGP, Martins TDD, Givisiez PEN, Furtado DA. Efeito do tempo de jejum pós-eclosão, valores energéticos e inclusão do ovo desidratado em dietas pré-iniciais e iniciais de pintos de corte. Revista Brasileira de Zootecnia 2009;38(2):314-22.

Tona K, Bamelis F, Ketelaere B, BruggemanV, Moraes V MB, Buyse J, et al. Effects of egg storage time on spread of hatch, chick quality, and chick juvenile growth. Poultry Science 2003;82(5):736-741.

Vieira SL, Moran ET. Broiler yields using chicks from extremes in breeder age and dietary propionate. Journal of Applied Poultry Research 1998;7(3):320-327 